\title{
УДК 575.21
}

\section{MONITORING OF EGGS PRODUCTIVITY OF THE SHAOXING BREED DUCKS OF DIFFERENT AGE}

\author{
A. M. CHEPIHA, S. O. KOSTENKO
}

National University of Life and Environmental Sciences of Ukraine

\section{P. V. KOROL}

Institute of Animal Breeding and Genetics nd. a. M. V. Zubets

National Academy of Agrarian Science of Ukraine

O. M. KONOVAL

Laboratory of quality and safety of agricultural products

National University of Life and Environmental Sciences of Ukraine

L. LU, X. BU, L. HUANG, X. HUANG,

Institute of Animal Husbandry and Veterinary Science Zhejiang Academy of Agricultural Sciences

\section{LI}

\section{Zhuji Guowei Poultry Development Co, Ltd.}

Abstract. The purpose of this study was to monitor the egg productivity of the Shaoxing breed ducks from the age of 24 (beginning of egg laying) and 75 (end of egg laying) weeks. According to the results of a study of over 2385 eggs, a significant difference was found between the weight indicators (57.93 $\mathrm{g}$ and $70.81 \mathrm{~g} ; \mathrm{p}<0.01$ ), the shape index $(73.71 \%$ and $75.35 \%, p<0.01)$, the strength of the shell $(4.92 \mathrm{~kg}$ and $4.28 \mathrm{~kg} ; p<0.01)$, the thickness of the shell of the egg $(0.48 \mathrm{~mm}$ and $0.45 \mathrm{~mm} ; p<0.01)$ in ducks at the age of 24 and 75 weeks. It also shows changes in the weight and shape of the egg with the age of the bird. The necessity of further studying the genetic diversity of birds, which causes the separate variability of indices of individual ducks, is substantiated.

Keywords. Egg mass, duck, shape index, The Shaoxing breed, morphological characteristics, egg productivity

The quality of the young birds and their further productivity depends not only on the conditions of incubation, but also on the biological parameters of the egg [5]. Bird's eggs have a typical oval shape, however, each species is characterized by certain features.

The main biological functions of the egg are its ability to create optimal conditions for embryos, which, accordingly, contributes to the preservation and reproduction of the species. Most of all hatching of chicks depends on the external 
Чепіга А. М., Костенко С. О., Король П. В., Коновал О. М., Лу Л., Бу С., Хуанг Л., Хуанг Ц., Лі Л.

(mass, shape, defects of the shell) and internal (the mass of egg white and yolk, the thickness of the shell) characteristics of the egg [15].

There are high requirements to the shape of the eggs. Eggs that have a standard shape are better stored during transportation. The shape of eggs is characterized by the shape index (the ratio of the small diameter of the egg to the large expressed in percentage). Normal shape index for uncalibrated chicken eggs is 74-78\% [1,2], and for ducks eggs it is $72-76 \%$ [24]. The higher the index of the egg shape index, the more eggs are rounded, and the lower, the eggs are more elongated and lengthened.

The shape and mass of eggs depends on heredity, age of the bird, season of the year and nutrition [13]. In the ducks of the Shaoxing breed, the average egg mass is 62-68 g [24].

The value of poultry eggs of all species, breeds, crosses and genotypes is known from many indicators. The most significant difference of eggs is by weight, especially in different types of poultry, for example, the weight of eggs of African ostriches is $1.4-2.0 \mathrm{~kg}$, in geese this index is $110-200 \mathrm{~g}$, the average weight of eggs of ducks and turkeys is 70-100 g, in chickens of different ages - 45-80 g, and quail eggs have a mass of 8-15 $\mathrm{g}[3]$.

The Shaoxing breed is one of the three major duck breeds in China. The bird of this breed is characterized by high performance: weight, early puberty, small live weight, and others. The Shaoxing breed is recognized as a valuable genetic resource among birds in China [24].

To date, the changes in the morphological characteristics of eggs in ducks, and the Shaoxing breeds in particular, remains poorly studied.

That is why the purpose of our study was to evaluate the morphological characteristics of eggs of ducks of all ages of the Shaoxing breed.

Materials and methods of research. An analysis of poultry egg productivity was conducted at a duck farm of Zhejiang Generation Biological Science and Technology Co., Ltd., located in the town of Chutki, Zhejiang Province, in the southeast of China, and at the laboratory of the Jjejiang Academy of Sciences 
Чепіга А. М., Костенко С. О., Король П. В., Коновал О. М., Лу Л., Бу С., Хуанг Л., Хуанг Ц., Лі Л.

Institute. For comparative analysis of the morphological characteristics of the production group of the Shaoxing ducks (more than 2000 birds of the same age, which were kept under identical feeding conditions in one poultry house), two experimental bird groups were selected. The first group included ducks that had just begun egg laying, at the age of 24 weeks, and the second group included birds at the end of their productive period, 75 weeks old. Experimental birds' eggs differed in shape, color, size and weight. A total of 2385 eggs were analyzed for 4 months.

The length (L) and width (W) of the eggs were measured with an accuracy of 0,1 mm by caliper. Weighing of eggs was carried out on electronic scales JM-A 20001 with an accuracy of $0,1 \mathrm{~g}$.

The egg shape index was calculated using the formula:

$$
\mathrm{SI}=(\mathrm{W} / \mathrm{L}) * 100[22] .
$$

The biometric processing of experimental data was conducted in accordance with generally accepted techniques on a PC using the Microsoft Office Excel 2010 table processor.

Results of the research and their discussion. One of the most important indicators of the food and incubation value of eggs is its mass. It has a direct effect not only on its caloric content, but also on the chemical composition [4].

Table 1 shows the results of the experiment to determine the change in mass, length, width and index of shape of the eggs of the Shaoxing breed ducks of different age. After analyzing the average egg mass values in Group 1 and Group 2, we found that this indicator is increasing with the age of duck. According to the Bureau of Product Quality (Chutki, China), the average weight of eggs, as a rule, should be 62$68 \mathrm{~g}$ [24]. Over time, the weight ratio in the experimental groups was $57.93 \pm 0.241$ (group 1) and $70.81 \pm 0.189$ (group 2). During the experiment, we observed a significant increase in the weight of the Shaoxing breed ducks with age $(p<0,01)$.

The weight and size of the eggs vary during the period of increase in bird's egg laying. According to BarbaraBiesiada-Drzazga [15], the mass of eggs of ducks of the Beijing breed during the experiment period (18 weeks) increased from 91.5 to $94.4 \mathrm{~g}$. 
Чепіга А. М., Костенко С. О., Король П. В., Коновал О. М., Лу Л., Бу С., Хуанг Л., Хуанг Ц., Лі Л.

Analysis of the mass of eggs of chicken cross "Loman White" by M.A. Derkho [4] shows that at age of 26 weeks, birds was laying eggs with an average weight of $57.7 \mathrm{~g}$, and at 80 weeks this figure was $62.2 \mathrm{~g}$.

Evaluating the quality of eggs, the first attention is paid to the strength and thickness of the shell, because the level of damage rate of the eggs depends on them; high level of damage rate causes a decrease in eggs grade and food safety [10].

After analyzing the strength of the shell in the ducks of different age groups, we came to the conclusion that with age this figure is reduced. In the birds of group 1, this indicator was $4.92 \pm 0.046 \mathrm{~kg}$, while group 2 showed $0.64 \mathrm{~kg}$ less $(4.28 \pm 0.031)$.

According to A. Rodriguez-navarro chickens of ISA Brown of different ages (30 and 58 weeks) have significantly different strength of the shell $(2.2 \pm 0.1$ and $1.04 \pm 0.09 \mathrm{~kg})$. The author attributes such a difference in the strength with agerelated changes in the egg shell [23].

We saw a similar tendency in examining the thickness of the egg shell. Eggs from the birds of group 1 had a thicker shell $(0,48 \pm 0,005 \mathrm{~mm})$ than eggs from group $2(0,45 \pm 0,006 \mathrm{~mm}, \mathrm{p}<0,01)$.

During the study of the strength of ISA Brown chicken eggs at the age of 30 weeks, a correlation was found between the thickness and strength of the egg shell. The strength of the shell increased with an increase in its thickness, although the correlation was rather weak $(r=0.35)$ [23].

An important indicator of egg quality is its shape, since it affects the position of the embryo during development [9]. An examination of the shape of an egg has attracted the attention of a number of researchers in recent years [19,21].

Having analyzed 2,285 eggs for four months, we found that in the first and second birds' group the average indexes of the egg shape were normal (Table 1). The average index of egg shape in the birds' group 1 was $73.71 \pm 0.095$, whereas at that time it was $1.64 \%$ higher in the group $2(75.35 \pm 0.108)$. According to the Bureau of Product Quality (Chutki, China), the shape index of eggs for the Shaoxing breed duck should be in the range of $72-76 \%$ [24]. 
Table 1. Average indicators of weight, size, and shape index of eggs in the Shaoxing breed ducks of different age during four months

\begin{tabular}{|c|c|c|c|c|}
\hline \multirow[t]{2}{*}{ Indicator } & \multicolumn{2}{|l|}{ Group 1} & \multicolumn{2}{|l|}{ Group 2} \\
\hline & $\mathrm{M} \pm \mathrm{m}$ & $\mathrm{Cv} \pm \mathrm{mCv}$ & $\mathrm{M} \pm \mathrm{m}$ & $\mathrm{Cv} \pm \mathrm{mCv}$ \\
\hline Egg mass, $\mathrm{g}$ & $57,93 \pm 0,241 *$ & $13,22 \pm 0,294$ & $70,81 \pm 0,189$ & $9,76 \pm 0,189$ \\
\hline Shape index,\%: & $73,71 \pm 0,095^{*}$ & $3,81 \pm 0,085$ & $75,35 \pm 0,108$ & $5,24 \pm 0,101$ \\
\hline $\begin{array}{l}\text { - longitudinal } \\
\text { diameter, sm }\end{array}$ & $57,04 \pm 0,098$ & $5,47 \pm 0,122$ & $60,35 \pm 0,080$ & $4,82 \pm 0,093$ \\
\hline $\begin{array}{ll}\text { - } & \text { transverse } \\
& \text { diameter, sm }\end{array}$ & $41,99 \pm 0,060$ & $4,50 \pm 0,100$ & $45,39 \pm 0,048$ & $3,86 \pm 0,075$ \\
\hline Shell thickness, kg & $4,92 \pm 0,046^{*}$ & $12,73 \pm 0,657$ & $4,28 \pm 0,031$ & $14,22 \pm 0,514$ \\
\hline Shell thickness, mm & $0,48 \pm 0,005^{*}$ & $7,98 \pm 0,776$ & $0,45 \pm 0,006$ & $10,61 \pm 0,878$ \\
\hline - dull end & $0,48 \pm 0,007$ & $10,55 \pm 1,025$ & $0,44 \pm 0,006$ & $10,60 \pm 0,877$ \\
\hline - equatorial part & $0,51 \pm 0,006$ & $9,07 \pm 0,881$ & $0,47 \pm 0,007$ & $12,13 \pm 1,004$ \\
\hline - sharp end & $0,47 \pm 0,006$ & $9,85 \pm 0,957$ & $0,44 \pm 0,006$ & $12,29 \pm 1,017$ \\
\hline
\end{tabular}

Notes: ${ }^{*} \mathrm{p}<0,01$

An increase in the egg shape index over bird's age was observed in studies by other scientists $[15,20,4,8]$. So, for example, in the Beijing breed of ducks. During the 18 weeks of the experiment, it fluctuated within 65-72\%. According to BarbaraBiesiada-Drzazga [15], this is due to the age of the bird. With the increase in the age of ducks, there is a tendency to increase the weight of the egg, which also affects the change of the shape index.

In chickens of age less than 45 weeks, the egg shape index was $74.4-77.5 \%$, while in the old birds it was $73.9-76.3 \%$. According to the researcher N. Nikolova [20], this is due to the fact that the young egg laying birds have a more rounded shape of eggs, and birds of age more than 45 weeks gave eggs of elongated shape, which is a characteristic feature of old chickens. 
Чепіга А. М., Костенко С. О., Король П. В., Коновал О. М., Лу Л., Бу С., Хуанг Л., Хуанг Ц., Лі Л.

In studies by M.A. Derkho [4] the egg shape index ranged from 71.5-74.9\%. The increase in the egg mass was accompanied by a decrease in the shape index, that is, the eggs became more elongated, which affected the damage rate of the shell.

Changes in the index of the shape of the egg over the age of the bird were described by MV Peters [8]. In the quail of the Pharaoh breed, with the increase in age, the weight of the egg increased (56-60 days - $12.7 \mathrm{~g} ; 148-150-15 \mathrm{~g}$ ), and with the increase in the egg mass, respectively, the index of shape decreased from $78.8 \%$ at the age of 56-60 days, to $75.7 \%$ at the age of $148-150$ days.

During the study of egg laying chickens [17], there was a statistically significant positive correlation between the shape index and egg mass $(\mathrm{p}<0.05)$. Many researchers observed a positive correlation between the shape index and the weight of eggs $[14,11]$, but there were cases where between these indicators there was also a negative correlation [18].

The study of eggs of the Japanese quail showed that there is a negative correlation between the egg shape index and the shell thickness [12]. Instead, according to M. Duman [17], the egg shape index for egg laying chickens does not affect the thickness of the egg shell. According to Altuntas [13], the average thickness of the shell increases with an increase in the shape index.

According to M. Duman, the influence of the egg shape index in the laying chickens on the shell strength was not discovered [17]. Blanco research [16] showed that the strength of the egg shell is positively correlated with the shape index ( $p$ $<0,05)$. Accordingly, the rounded eggs have a high stability of the shell. 


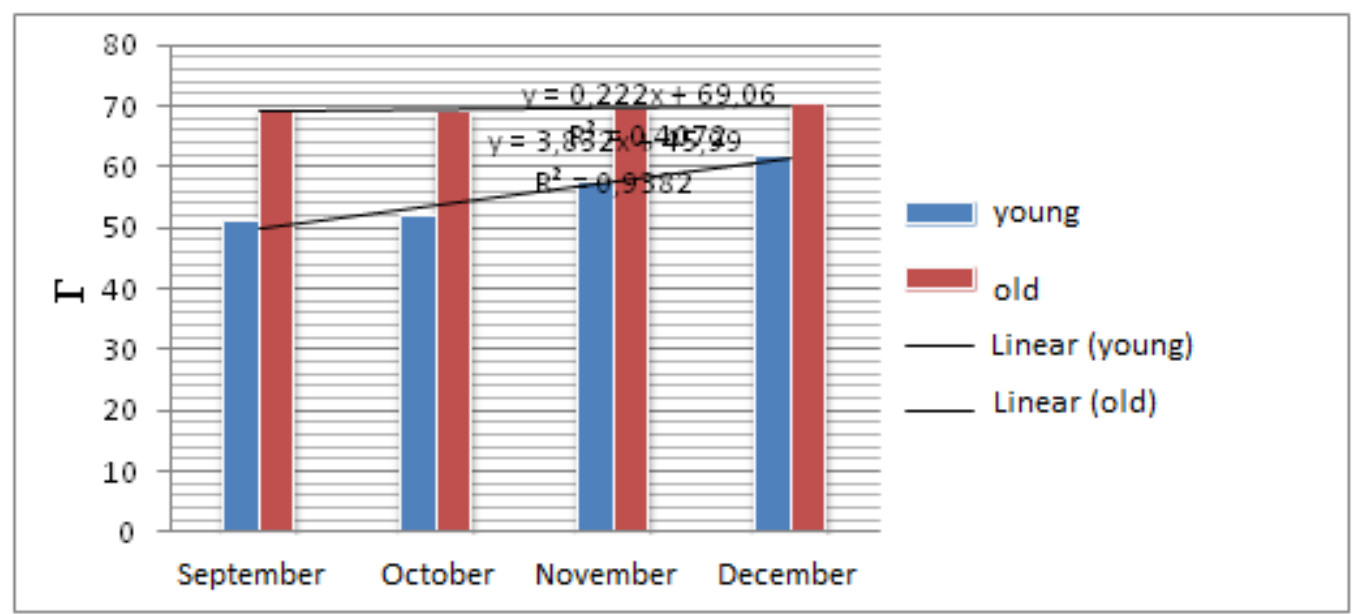

\section{Fig.1 Change in egg mass in ducks of the Shaoxing breed over time, $g$}

By comparing the weight of eggs from the Shaoxing breed ducks (Fig. 1) for four months, we found that this index is increasing with age. At the beginning of the eggs laying (group 1), the average weight of the egg was $51.01 \mathrm{~g}$, and by the end of the experiment it increased by $10.95 \mathrm{~g}$. In the ducks of group 2 (end of eggs laying) at the beginning of the experiment, the average weight of the egg was $69.61 \mathrm{~g}$, and at the end of the study, it increased only by $0.56 \mathrm{~g}$.

As a whole, it can be noted that the average weight of eggs from ducks in groups 1 and 2 corresponds to the norm, because according to the standard [24], ducks of the Shaoxing breed should have eggs of 62-68 g, and at the end of the egg laying period it becomes relatively stable (69-70 g )

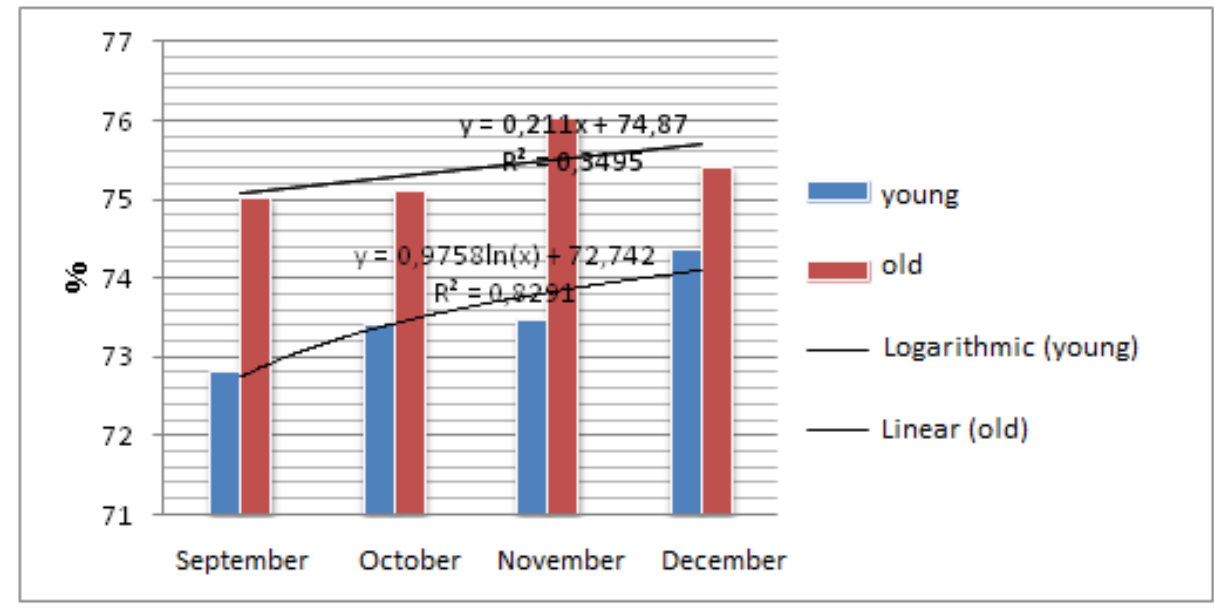

Fig.2 Changing the egg shape index in the Shaoxing breed ducks over time, $\%$ 
Чепіга А. М., Костенко С. О., Король П. В., Коновал О. М., Лу Л., Бу С., Хуанг Л., Хуанг Ц., Лі Л.

After analyzing the changes in the shape index in Shaoxing breed ducks over time, we came to the conclusion that this figure is increasing with age. At the start of the experiment in the bird of group 1, it was $72.82 \%$, and in the end $-74.38 \%$. In the group 2 ducks during the experiment period, the shape index increased by only $0.39 \%$ (the beginning of the experiment was $75.03 \%$, end of the experiment - 75.42\%). Consequently, in the birds of group 2, the egg shape index was more averaged, as opposed to in young ducks (group 1), it increased with each month of the study.

Correlation analysis of physical and morphological indicators of eggs in the Shaoxing breed ducks of different ages allowed to reveal a strong connection between the weight of the egg and its longitudinal diameter $(r=0,8648 \pm 0,00794)$, the mass and the diameter of the egg $(r=0,9133 \pm 0,00522)$, between the longitudinal and transverse diameters $(r=0,6781 \pm 0,01701)$, a negative correlation between the longitudinal diameter and the egg shape index $(r=-0,5754 \pm 0,02106)$ was also discovered in the ducks group 1. In the eggs attributed to group 2, the positive correlation was found between the egg weight and its longitudinal diameter $(\mathrm{r}=$ $0,6821 \pm 0,01463)$, mass and diameter $(r=0,8311 \pm 0,00846)$, transverse diameter and shape index $(r=0,4675 \pm 0,02138)$. Negative correlation was observed in this group of birds between the transverse diameter and the shape index $(r=-0.7083 \pm$ $0.01363)$.

Throughout the time of experiment, we observed that with age, the physical and morphological parameters of eggs are changing. The weight and index of the shape of the egg with age tend to increase, and the strength of the shell and the thickness of the egg shell, by contrast, decrease

Conclusions and perspectives of further research. Thus, according to the results of monitoring the egg productivity of ducks of all ages of the Shaoxing breed, it was found that with an increase in the age of the bird, there is an increase in the average weight of the egg (from $57.93 \mathrm{~g}$ to $70.81 \mathrm{~g}$; $\mathrm{p}<0.01$ ), there is a slight increase in the shape index (from $73,71 \%$ to $75.35 \% ; \mathrm{p}<0,01$ ). Also, during the experiment there was a decrease in the strength of the egg shell with an increase in the age of bird 
Чепіга А. М., Костенко С. О., Король П. В., Коновал О. М., Лу Л., Бу С., Хуанг Л., Хуанг Ц., Лі Л.

(from $4.92 \mathrm{~kg}$ to $4.28 \mathrm{~kg} ; \mathrm{p}<0,01$ ). The study of egg shell thickness showed that this indicator tends to decrease with age (from $0.48 \mathrm{~mm}$ to $0.45 \mathrm{~mm}$; $\mathrm{p}<0.01$ ). A positive correlation was observed between the egg weight and its longitudinal diameter $(\mathrm{r}=$ $0.8684)$, the mass and diameter of the egg $(r=0.9133)$, between the longitudinal and transverse diameters $(r=0.681)$ in the ducks at the age of 24 weeks, as well as ducks aged 75 weeks between egg weight and its longitudinal diameter $(r=0.6821)$, mass and diameter $(r=0.8311)$, diameter and shape index $(r=0.4675)$. Instead, a negative correlation was found in the young birds between the longitudinal diameter and the egg shape index $(r=-0.5754)$, and in the old birds between the transverse diameter and the shape index $(r=-0.7083)$.

In the future, it is necessary to investigate the egg productivity of ducks based on their genotypes, which will allow selection of poultry with optimal individual productivity.

This study was supported by the Earmarked Fund for National Waterfowlindustry Technology Research System (CARS-42-06) and the Zhejiang Major Scientific and Technological Project of Agricultural (livestock's) Breeding (grant number 2016C02054-12).

\section{Referens}

1. Бессарабов Б. Ф.Методы оценки качества яиц/ Б. Ф. Бессарабов, Н. П. Мишуров, А. А. Усов - - Ефективне птахівництво. - 2005. - № 2 (2). - С. $17-23$.

2. Бородай В. П.Якість і безпека харчових яєць / В. П. Бородай, Н. П. Пономаренко, В. В. Мельник. - Сучасне птахівництво.- 2006. - № 11. - С. $11-13$.

3. Вертійчук А.І. Різноманітністьпоказниківкурячихяєцьдляселекції/ А. І. Вертійчук, Ю. А. Глєбова. - Науковий вісник НУБІП України. - 2014. - С. $230-234$.

4. Дерхо М. А. Анализ корреляционных связей массы яйца с показателями качества пищевых яиц/ М. А. Дерхо , Т. И. Середа, Л. Ш. Горелик. - Известия Оренбургского государственного университета. 2014.- C. $172-175$.

5. Дядичкина Л. Инкубационные качества яицвысокопродуктивных мясных кроссов /Л. Дядичкина, Т. Цилинская, Н. Позднякова, Т. Мелёхина.Птицеводство. - 2011. - №1. - С.25-27. 
Чепіга А. М., Костенко С. О., Король П. В., Коновал О. М., Лу Л., Бу С., Хуанг Л., Хуанг Ц., Лі Л.

6. Ермашкевич Е.И. Наиболее распространенные дефекты куриного яйца/ Е. И. Ермашкевич, О. Ю. Копоть, Н. Н. Якименко, А. Н. Мартынов, Б. Ф. Бессарабов, В. В. Пронин, Л. В. Клетикова, М. С. Дюмин. - Росийский ветеренарный журнал. - 2015. - № 1. - С. 30 - 32.

7. Методические рекомендации для зоотехнических лабораторий птицеводческих мероприятий /Под ред. А. Н. Тищенкова. - Загорск ВНИИТИП., 1982. - 156 с

8. Петерс М. В.Оцінка морфологічних показниківінкубаційних яєць перепелів породифараон залежно від віку/ М. В. Петерс.- Сучасне птахівництво. - 2013.- № 9 (130). - С. 24-25.

9. Станишевская О. Повышение качества инкубационных яиц /О. Станишевская.- Птицеводство. - 2008. - № 9. - С.15-17.

10. Царенко П.П. Прочность - главное качество яиц/ П. П. Царенко, Л. Т. Васильева, Е. В. Осипова.- Птица и птицепродукты.- 2012.- № 5.- С.51-54.

11. Aktan S. Determining Some Exterior and Interior Quality Traits of Quail Eggs and Phenotypic Correlations by Digital Image Analysis / S. Aktan.- Hayvansal Üretim.- 2004.- 45(1).- P. 7-13.

12. Alkan S. Effects of selletion for body weight and egg production on egg quality traits in Japanese quails (Coturnix coturnix japonica) of different lines and relationships between these traits/ S. Alkan, K. Karabag, A. Galic, T. Karsli, M. S. Balcioglu.-Kafkas Univ. Vet. Fak. Derg.- 2010.- 16(2).- P. 239-244.

13. Altuntas E. Effect of egg shape index on mechanical properties of chicken eggs / E. Altuntas, A. Sekeroglu.- Journal of Food Engineering.- 2008.- 85.P. 606-612.

14. Aygun A. The Relationship among egg quality characteristic of different hybrid layers to forced molting programs with and without feed withdrawal/A. Aygun, R. Yetisir.-Journal of Animal and Veterinary Advances.- 2010.- 9.- P. 710715 .

15. Barbara Biesiada-Drzazga. Evaluation of particular traits of pekin duck breed star 53 of French origin eggs during egg laying/ Barbara Biesiada-Drzazga, Anna Charuta, DorotaBanaszewska.- Veterinarijairzootechnika.-2014.- T. 67 (89).P.3-9.

16. Blanco A.E. Genetic parameters of egg quality traits on different pedigree layers with special focus on dynamic stiffness/ A.E. Blanco, W. Icken, D. Ould-Ali, D. Cavero, M. Schmutz.- Poultry Science.- 2014.- 93.- P. 2457-2463.

17. Duman M. Relation between egg shape index and egg quality characteristics/ M. Duman, A. Şekeroğlu, A. Yıldırım, H. Eleroğlu, Ö. Camc1.Europ.Poult.Sci.J.- 2016.- 80.- P.1-9.

18. Kul S. Phenotypic correlations between some external and internal egg quality traits in the Japanese Quail (Coturnix coturnix japonica)/ S. Kul, I. Seker.International Journal of Poultry Science.- 2004.- 3(6).- P. 400-405.

19. Monus F. Repeatability analysis of egg shape in a wild tree Sparrow (passer montanus) population: a sensitive method for egg shape description/ F. 
Чепіга А. М., Костенко С. О., Король П. В., Коновал О. М., Лу Л., Бу С., Хуанг Л., Хуанг Ц., Лі Л.

Monus, Z. Barta.- Acta Zoologica Academiae Scientiarum Hungaricae.- 2005.51(2).- P. 151-162.

20. NedeljkaNikolova. Forming egg shape index as influenced by ambient temperatures and age of hens/ NedeljkaNikolova, Kocevski D. - Biotechnology in Animal Husbandry.-2006.- 22 (1-2).-P. 119-125.

21. Nedomova S. Influence of hen egg shape on eggshell compressive strength/ S. Nedomova, L. Severa, J. Buchar.- Int. Agrophysics.- 2009.- 23.- P. 249256.

22. Reddy P. M. Egg weight, shape index and hatchability in khaki Campbell duck egg/ P.M.Reddy, V.R. Reddy, C.V. Reddy, S.P. Rap.- Ind. J. Poult. Sci.- 1979.- 14.- P. 26.31.

23. Rodriguez-Navarro A. Influence of the microstructure and crystallographic texture on the fracture strength of hen's eggshells/ A. RodriguezNavarro, O. Kalin, Y. Nys, JM. Garcia-Ruiz .- Br. Poult. Sci. .- 2002.- № 43.- P. 395-403.

24. Shaoxing Ducks [S]: DB 33068/T 02.1-2012.-Zhuji: Zhuji Quality and Technique Supervision Bureau, 2012.- (National Standard of China).- P.40.

25. Stadelman W.J. Factorsinfluencingcompositionofthehen'segg/ W.J Stadelman, D.E Pratt. - World'sPoult. Sci. J.-1989.- 45.-P. 247-266.

26. World watch list for domestic animal diversity: Food and Agriculture organization of the United Nations [Edited by Beate D. Scherf] - Rome.- 2000.- 3 th edition.- P.726.

27. Wucheng B. The research on the origin of the house-duck in China/ B. Wucheng. - In The Satellite Conference for the18th World's Poultry Congress. - China. - 1988. - P.125-129.

\section{МОНТТОРИНГ ЯЕЧНОЇ ПРОДУКТИВНОСТІ КАЧОК РІЗНОГО ВІКУ ПОРОДИ SНАОХING}

А. М. Чепіга, С. О. Костенко, П. В. Король, О. М. Коновал, Л. Лу, С. Бу, Л. Хуанг, Ц. Хуанг, Л. Лі,

Анотація. Метою даного дослідження було провести моніторинг яєчної продуктивності качок породи Шаосінь (Shaохіng) віком 24 (початок яйцекладки) та 75 (кінець яйцекладки) тижнів. За результатами дослідження понад 2385 яєиь, була встановлена достовірна різниця між показниками маси $(57,93$ г $i$ 70,81 2; $p<0,01)$, індексу форми $(73,71 \% i$ 75,35\%; $p<0,01)$, міцуності шкаралупи (4,92 кг i 4,28 к2; $p<0,01)$, товщзиною оболонки яйця (0,48 мм і 0,45 мм; $p<0,01)$ у качок віком 24 та 75 тижнів. Також показані зміни маси та індексу форми яєць з віком птищі. Обгрунтована необхідність подальшого вивчення генетичного різноманіття птиці, яке обумовлює індивідуальну мінливість показників окремих особин.

Ключові слова. Маса яєщь, качка, індекс форми, порода Shaoxing, морфологічні показники, яєчна продуктивність 
Чепіга А. М., Костенко С. О., Король П. В., Коновал О. М., Лу Л., Бу С., Хуанг Л., Хуанг Ц., Лі Л.

\section{МОНИТОРИГ ЯИЧНОЙ ПРОДУКТИВНОСТИ УТОК РАЗНОГО ВОЗРАСТА ПОРОДЫ SHАОХING}

А. М. Чепига, С. А. Костенко, П. В. Король, О. Н. Коновал, Л. Лу, С. Бу., Л. Хуанг, Ц. Хуанг, Л. Ли

Анотация. Целью нашего исследования было провести мониторинг яичной продуктивности уток породы Шаосин (Shaoxing) возрастом 24 (начало яйцекладки) и 75 (конеи яйцекладки) недель. Соответственно к результатам исследования (2385 яии), было установлена достоверная разница между показателями массы (57,932 $i$ 70,812; $p<0,01)$, индекса формы $(73,71 \%$ i 75,35\%; $p<0,01)$, прочности скорлупы (4,92кг i 4,28кг; $p<0,01)$, толщины оболочки яйца $(0,48 \mathrm{мм} i$ 0,45мм; $p<0,01)$ у уток возрастом 24 и 75 недель. Также показаны изменения массы и индекса формы яии с возрастом птицы. Обоснована необходимость дальнейшего изучения генетического разнообразия птииы, которое обуславливает индивидуальную изменчивость показателей отдельных особей.

Ключевые слова. Масса яии, утка, индекс формы, порода Shaoxing, морфологические показатели, яичная продуктивность 